Niniejsza publikacja jest dostępna na licencji Creative Commons. Uznanie autorstwa-Użycie niekomercyjne-Bez utworów zależnych 3.0 Polska. Pewne prawa zastrzeżone na rzecz autora. Zezwala się na wykorzystanie publikacji zgodnie z licencja - pod warunkiem zachowania niniejszej informacji licencyjnej oraz wskazania autora jako właściciela praw do tekstu. Treść licencji jest dostępna na stronie: http://creativecommons.org/licenses/by-nc-nd/3.0/pl/

Lingwistyka Stosowana 24: 4/ 2017, 149-163

\author{
Joanna OSIEJEWICZ
}

Uniwersytet Zielonogórski

\title{
Sprawiedliwość językowa w prawie środowiska: ludy tubylcze a narody Unii Europejskiej
}

\begin{abstract}
:
Linguistic justice in environmental law: the indigenous peoples and the nations of the European Union

One of the conditions for the effectiveness of guarantees attributed to peoples by international environmental law is their proper communication aimed at enabling these peoples to participate in the management of public affairs. The essence of communication with indigenous peoples is to obtain their consent to undertake operations that may carry a risk of harm to the environment. Communication with the EU nations takes place, on the other hand, by means of the EU secondary legislation. Although the subject in each of these cases is the peoples, and the purpose - conservation of the environment, different conceptual tools and methods of action apply. It is therefore reasonable to answer the question as to how these tools and methods enrich or limit the realization of claims in the linguistic aspect. The purpose of the paper is to reconstruct the assumptions about how to communicate with the peoples and to explore the conceptual framework that determines the concept of linguistic justice in international environmental law.
\end{abstract}

\section{Wstęp}

Pojęcie sprawiedliwości nie ma charakteru homogenicznego i nie jest właściwe jedynie dla nauk prawnych (J. Zajadło 2007: 316), trudno zatem o jego jednoznaczną definicję w nauce prawa międzynarodowego. W doktrynie przyjmuje się często uproszczone rozumienie sprawiedliwości międzynarodowej, określając ją jako zbiór reguł kierujący wzajemnymi relacjami i zachowaniem państw oraz innych uczestników stosunków międzynarodowych (M. Soniewicka 2010: 1). Tak rozumiana sprawiedliwość międzynarodowa dotyczyć ma dystrybucji praw i obowiązków na poziomie państw, regulowanej przez normy prawa międzynarodowego. Nie jest jednak ograniczona do relacji miedzy państwami, lecz odnosi się również do osób lub grup zamieszkujących te państwa (A. Buchanan/ D. Golove 2012: 903). Problematyka sprawiedliwości jest obecna w prawie międzynarodowym w różnych aspektach. Konsekwencją przemian zachodzących w społeczności międzynarodowej oraz tendencji rozwojowych prawa międzynarodowego, w tym rozwoju idei i ochrony praw człowieka w sferze prawnomiędzynarodowej jest to, iż ograniczanie sprawiedliwości międzynarodowej 
do jej klasycznego ujęcia nie wydaje się właściwe (A. Wiśniewski 2016: 503). Wyodrębniając aspekt językowy sprawiedliwości prawnomiędzynarodowej, można sprawiedliwość językową na gruncie prawa międzynarodowego określić jako taki rodzaj sprawiedliwości dystrybutywnej, który umożliwi realizację praw i obowiązków dzięki zastosowaniu odpowiedniego kanału komunikacji i przekazaniu wiedzy odbiorcy komunikatu w sposób zrozumiały, poprzez użycie precyzyjnych terminów określających uprzednio wyczerpująco objaśnione pojęcia.

Zasady prawa środowiska, wyrażone pozornie nieskomplikowanymi terminami, zyskały specyficzne znaczenie specjalistyczne. Liczne akty prawne przyjęte w dziedzinie prawa środowiska zarówno na poziomie uniwersalnym jak i regionalnym stosują te terminy na określenie nowych pojęć o szerokim zakresie znaczeniowym. Jednym $z$ warunków skuteczności praw przyznanym narodom przez międzynarodowe prawo środowiska, jak również możliwości żądania przez te narody realizacji obowiązków leżących po stronie państw, jest efektywne zakomunikowanie tych praw i obowiązków w taki sposób, aby narody te mogły skutecznie uczestniczyć w kierowaniu sprawami publicznymi (por. S. Grucza 2010: 54-67).

Istotą przedmiotowej komunikacji z ludami tubylczymi jest uzyskanie ich zgody na podejmowanie operacji niosących ryzyko szkód w środowisku naturalnym. Komunikacja z narodami Unii Europejskiej (dalej UE) następuje natomiast w drodze stanowienia prawa wtórnego przez instytucje unijne. Mimo że adresatem komunikatu w każdym z tych przypadków jest naród, a celem komunikacji - zachowanie środowiska naturalnego, stosuje się skrajnie odmienne narzędzia pojęciowe i metody komunikacji. Zasadnym jest zatem udzielenie odpowiedzi na pytanie, czy i w jaki sposób te narzędzia i metody wzbogacają lub ograniczają na poziomie językowym realizację roszczeń narodów dotyczących czystego środowiska. Celem artykułu jest zrekonstruowanie założeń dotyczących sposobów uczestnictwa językowego ludów tubylczych oraz narodów UE w realizacji praw i obowiązków wynikających z prawa środowiska, poprzez zbadanie ram pojęciowych, które determinują koncepcję właściwej im sprawiedliwości językowej w prawie środowiska, jak również stosowanych w tym obszarze kanałów komunikacji i sposobów wyrażania wiedzy.

\section{Komunikacja jako warunek realizacji prawa do uczestnictwa}

Międzynarodowe traktaty ochrony praw człowieka potwierdzają podstawowe prawa, które odnoszą się do uczestnictwa społeczeństwa, obejmującego nie tylko prawo obywateli do głosowania, lecz również uczestnictwo w kierowaniu sprawami publicznymi (art. 25 Międzynarodowy Pakt Praw Obywatelskich i Politycznych, patrz także art. 23 American Convention on Human Rights i art. 13 African Charter on Human and Peoples' Rights). Komitet Praw Człowieka ONZ, który nadzoruje realizację Międzynarodowego Paktu Praw Obywatelskich i Politycznych (Dz.U. 1977 nr 38 poz. 167) wyjaśnił, że prawo do uczestnictwa dotyczy wszystkich aspektów administracji publicznej oraz formułowania i wdrażania polityki na szczeblu międzynarodowym, krajowym, regionalnym i lokalnym (General Comment No. 25, 1996, par. 5). Wskazał również, że niezależnie od prawa głosu, obywatele mogą brać udział w sprawach publicznych w inny sposób, w tym wywierając wpływ poprzez debaty publiczne i dialog 
z udziałem ich przedstawicieli lub poprzez realizację ich zdolności do organizowania się. Uczestnictwo zyskuje wsparcie dzięki zapewnieniu wolności słowa, zgromadzeń i zrzeszania się (General Comment No. 25, 1996, par. 8).

Tak zwane „prawa proceduralne” mogą umożliwić opinii publicznej wywieranie wpływu na podejmowanie decyzji dotyczących środowiska (Zasada 10 Deklaracji z Rio 1992). Prawa te obejmują dostęp do informacji, udział społeczeństwa w podejmowaniu decyzji publicznych oraz środki prawne przysługujące wobec niekorzystnych decyzji. Konwencja o dostępie do informacji, udziale społeczeństwa w podejmowaniu decyzji oraz dostępie do sprawiedliwości w sprawach dotyczących środowiska, podpisana 25 czerwca 1998 w Aarhus, w Danii, podczas IV Paneuropejskiej Konferencji Ministrów Ochrony Środowiska (Dz. U. nr 78 poz. 706) potwierdza istnienie takich praw procesowych, w państwach, które ją ratyfikowały (konwencja weszła ona w życie 30 października 2001 r.). Wspólnota Europejska przyjęła konwencję z Aarhus na mocy Decyzji Rady 2005/370/WE (Dz. Urz. UE L 186, 19.7.2017: 1516). Konwencja $z$ Aarhus potwierdza prawo ,zainteresowanej społeczności” (the public concerned), czyli tych, którzy mogą zostać dotknięci skutkami decyzji, do informacji o proponowanych projektach, mogących mieć znaczący wpływ na środowisko. Zainteresowana społeczność ma również prawo do udziału w podejmowaniu decyzji i może oczekiwać od decydentów wzięcia jej opinii pod należytą uwagę (art. 6 Dz. U. nr 78 poz. 706). Konwencja z Aarhus potwierdza ponadto prawo obywateli do uzyskiwania dostępu do informacji o środowisku, wskazując jednak na możliwe wyjątki ze względu na poufność informacji handlowych i przemysłowych (art. 4 Dz. U. nr 78 poz. 706). Ponadto aprobuje prawo zainteresowanej społeczności do uzyskania dostępu do sądowych procedur odwoławczych na potrzeby kwestionowania legalności decyzji, aktów lub zaniechań (art. 9 Dz. U. nr 78 poz. 706). Konwencja z Aarhus dotyczy nie tyle samej ochrony środowiska, co prawa człowieka do czystego środowiska. W tym sensie prawo do informacji, do udziału w podejmowaniu decyzji i dostępu do sądownictwa w ochronie środowiska są często określane jako „następna generacja" praw człowieka i jako takie stanowią kluczowy element realizacji zasady zrównoważonego rozwoju. Realizacja uprawnień przewidzianych Konwencją z Aarhus wymaga zastosowania właściwego kanału komunikacji, właściwego dla konkretnej zainteresowanej społeczności.

Uczestnictwo społeczeństwa w zarządzaniu środowiskiem sprzyja przejrzystości, która może być kluczowym czynnikiem przyczyniającym się do zwiększenia efektywności polityki publicznej. Perspektywa kontroli publicznej opartej na przejrzystości przeciwdziała marnotrawstwu i zachęca do rozwijania odpowiedniej zdolności instytucjonalnej. Przejrzystość działań rządu i prawa obywateli do dostępu do informacji są powszechnie postrzegane jako mające fundamentalne znaczenie dla funkcjonowania demokratycznego społeczeństwa (M.L. Ross 2012). Istotą demokracji przedstawicielskiej jest świadoma zgoda, warunkiem której jest uprzednie ujawnienie informacji na temat polityki i praktyk rządowych. Świadoma, demokratyczna debata może, między innymi, umożliwić zmotywowanym decydentom pozyskanie informacji zwrotnych na temat praktycznych efektów ich polityki. Takie sprzężenie jest możliwe jedynie w przypadku funkcjonowania swobodnego i efektywnego przepływu informacji w obu kierunkach. 


\section{Uczestnictwo ludów tubylczych w projektach mających wpływ na środowisko}

W prawie międzynarodowym brak jednolitej definicji ludności tubylczej (w jęz. polskim stosuje się również termin „ludność rdzenna”). Najczęściej jest ona charakteryzowana poprzez specyficzne dla niej cechy szczególne. Dla potrzeb niniejszego artykułu przyjęto charakterystykę ludów tubylczych wypracowaną przez Bank Światowy - organizację, której celem działalności jest podnoszenie standardu życia w słabiej rozwiniętych krajach, m.in. poprzez inwestowanie w projekty mające na celu rozwój opieki zdrowotnej, edukacji i ochrony środowiska. W 1991 r. Bank Światowy wprowadził regulację pod nazwą Dyrektywa 4.20, zgodnie z którą Bank Światowy nie będzie brał udziału w projektach, o których wiadomo, że będą związane z wkraczaniem na tereny tubylcze, chyba że zapewnione zostaną odpowiednie środki, które uchronią przed niepożądanymi dla ludności tubylczej konsekwencjami tychże projektów (zob. np. S. Wiesner 1999: 107). Zakładając, iż poszczególne państwa stosują odmienne określenia ludności tubylczej, Bank Światowy przyjął politykę, zgodnie z którą nie stosuje jednolitej definicji, lecz zwraca uwagę na obecność wyróżniających daną grupę cech: bliski związek z ziemią przodków; obecność tradycyjnych, społecznych i politycznych instytucji; język tubylczy odmienny od dominującego; samoidentyfikacja i uznanie przez innych za grupę odmienną kulturowo; specyfika systemu ekonomicznego (E. Daes 2008: 21). O „stopniu tubylczości” danej grupy - na podstawie wymienionych powyżej kryteriów - ostatecznie decyduje Zarząd Banku (J. Corntassel 2008: 61). Najważniejszym zagrożeniem dla ludności tubylczej jest postępująca akulturacja i różne formy dyskryminacji przez dominujące warstwy społeczne. Częstą przyczyną tego rodzaju problemów jest konflikt o zasoby (por. J. Osiejewicz 2017b: 445-459), prowadzący do wysiedleń, a następnie marginalizacji ludności tubylczej w nowym miejscu zamieszkania.

Jednym z najważniejszych prawnomiędzynarodowych zabezpieczeń ludności tubylczej jest zasada uzyskania swobodnej, uprzedniej i świadomej zgody (free, prior, and informed consent) tej ludności na projekty przemysłowe mające wpływ na środowisko, w którym żyje dana grupa (UNDRIP art. 32 ust. 2). Wymóg uzyskania zgody zobowiązuje rządy, a także, przedsiębiorstwa, do zapewnienia, aby rdzenne społeczności wyrażające zgodę na projekt zostały odpowiednio poinformowane o możliwych pozytywnych i negatywnych skutkach projektu i aby ich zgoda została wyrażona przed rozpoczęciem projektu oraz bez wywierania na nie nacisku bądź wpływu. Społeczności powinny także być w stanie skutecznie uczestniczyć w procesie zatwierdzania projektów.

Wymóg uzyskania swobodnej, uprzedniej i świadomej zgody ludności tubylczej na mocy międzynarodowych praw człowieka wynika przede wszystkim z zastosowania do tego podmiotu prawa do samostanowienia ujętego w międzynarodowych paktach praw człowieka. Prawo to derywowane jest ponadto od innych praw, w tym prawa do rozwoju i utrzymania ich kultury, zgodnie z art. 27 Międzynarodowego Paktu Praw Obywatelskich i Politycznych (patrz w szczególności R. Wieruszewski 2012: 682-695.) oraz art. 15 Międzynarodowego Paktu Praw Gospodarczych, Społecznych i Kulturalnych (Dz. U. 1977 nr 38 poz. 169). Wymóg ten wykazuje również związek z zasadą niedyskryminacji ludności rdzennej. W komentarzu nr XXIII z 1997 
r. w sprawie ludności rdzennej (U.N. Doc. A/52/18), Komitet w sprawie likwidacji wszelkich form dyskryminacji rasowej wyjaśnił, że dla zapewnienia praw ludności rdzennej, w tym prawa do własności, w sposób niedyskryminacyjny konieczne jest, aby żadne decyzje odnoszące się bezpośrednio do praw i interesów ludności tubylczej nie były podejmowane bez ich świadomej zgody. W komentarzu nr XXI z 2009 r. w sprawie powszechnego prawa do udziału w życiu kulturalnym, Komitet Praw Gospodarczych Społecznych i Kulturalnych potwierdził obowiązek państw uzyskania swobodnej, uprzedniej i świadomej zgody rdzennej ludności we wszystkich sprawach objętych ich szczególnymi uprawnieniami (General Comment XXI 2009: §36-37). Również Deklaracja ONZ w sprawie praw ludności rdzennej (A/RES/61/295 2007) wskazuje, że ludy tubylcze mają prawo do wyrażenia swobodnej, wcześniejszej i świadomej zgody, które powinno być przestrzegane przed realizacją wszelkich projektów mających wpływ na ich życie i że należy przyjąć regulacje w celu zapewnienia przestrzegania tego wymogu (C. Doyle 2012: 179-181).

Obowiązek uzyskania zgody dotyczy wszystkich tradycyjnych terytoriów ludów tubylczych pozostających pod bezpośrednim lub pośrednim wpływem projektu mogącego mieć wpływ na środowisko, niezależne od tego, czy nadano tym terytoriom formalną nazwę (A/HRC/12/34 §44). Podstawą powiązania ludności tubylczej z danym terytorium są czynniki społeczne, kulturowe i duchowe, a także bezpośrednie oddziaływanie fizyczne (ILO Convention 1989 art. 7 ust. 1). Przedsiębiorstwa mogą identyfikować odnośne grupy społeczne i zainteresowane podmioty poprzez przeprowadzanie analizy oddziaływania, zwykle w odniesieniu do środowiska, lecz także do aspektów społecznych, zdrowotnych, kulturalnych i/ lub wpływu na prawa człowieka (patrz na temat due dilligence J. Osiejewicz 2017a: 152-155). Analizy te często rozpoczynają się od ustalenia wymogów prawnych dotyczących konsultacji lub negocjacji ze zidentyfikowanymi uprzednio społecznościami. Przedsiębiorstwa mogą również prowadzić badania antropologiczne i demograficzne, takie jak badania etnograficzne i mapowanie społeczne, w celu lepszego zrozumienia lokalnych grup i kultur służącego ustaleniu, kto powinien być stroną konsultacji. Takie działania sprzyjają zapewnieniu włączenia grup lub osób, których zidentyfikowanie w zwykłych procesach konsultacyjnych byłoby utrudnione (Joint Working Group on Indigenous Land Settlements 2009: 8).

Udzielenie zgody następuje poprzez przedstawicieli i instytucje wyłonione przez ludność rdzenną zgodnie z ich własnymi procedurami (UN Declaration on the Rights of Indigenous Peoples art. 18, 19,32). Ludność rdzenna powinna określić, zgodnie ze swoim zwyczajem i tradycją, z kim należy przeprowadzić konsultacje i kto powinien wyrazić zgodę na działania, pod wpływem których ludność ta pozostaje (Saramaka People v. Suriname 2008 §18-22). Oprócz uprawnienia do reprezentacji przez struktury wyłonione wedle własnego wyboru, ludność rdzenna ma również prawo wzmacniać lub modyfikować swoje instytucje, a nawet tworzyć nowe struktury reprezentacji dla ułatwienia ich zaangażowania w aktualne procesy decyzyjne dotyczące projektów (UN Doc. A/66/288 2011: §89). Wskazane jest także ustalenie sposobu, w jak przedstawiciele władz lokalnych i/ lub rządu wezmą udział w negocjacjach. Rządy państw mogą zarówno ułatwiać negocjacje pomiędzy przedsiębiorstwem a społecznością, jak 
i brać udział w negocjacjach jako niezależna osoby trzecia. W niektórych przypadkach zasadne może być prowadzenie negocjacji bez żadnego udziału rządu (J. Loutit/ J. Mandelbaum/ S. Szoke-Burke 2015: 76).

Zgodnie z zaleceniem Konwencji Międzynarodowej Organizacji Pracy nr 169, która uznaje zbiorowe prawa ludności rdzennej do ziem i uczestnictwa oraz potwierdza wymóg proceduralny przeprowadzenia konsultacji, których celem musi być uzyskanie zgody tej ludności, konsultacje muszą zostać podjęte w dobrej wierze oraz w formie odpowiedniej do okoliczności (ILO Convention 1989 art. 2, 6, 15, 16). Ponadto, konsultacje powinny być prowadzane w procesie właściwym kulturowo, z poszanowaniem zwyczaju i lokalnej praktyki, a także w poszanowaniu właściwych praw (The World Bank's Operational Policy, 4.10 Annex A §2c). Procedury muszą uwzględniać odpowiedni termin dla rdzennej ludności na przeprowadzenie ich własnych procedur decyzyjnych $\mathrm{w}$ zgodzie $\mathrm{z}$ ich tradycjami społecznymi i kulturowymi (UN Doc. CERD/C/PHL/CO/20 2009). Jednym z mechanizmów sprzyjających ukształtowaniu takich procedur jest udzielanie przez państwo wsparcia dla wypracowania praktyki ludności rdzennej w zakresie formalizowania własnych charakterystycznych konsultacji, protokołów zgody lub polityk (Nagoya Protocol on Access to Genetic Resources 2010). Dobre praktyki wymagają akceptacji propozycji składanych przez przedstawicieli ludności tubylczej w odniesieniu do produry konsultacji (GB. 294/17/1 2007: §53), która musi zostać uzgodniona zanim przedsiębiorstwa i państwa zawrą umowy w odniesieniu do proponowanych projektów (UN Doc. A/66/288 2011: §88). Dla uzyskania klimatu zaufania i wzajemnego szacunku, procedura konsultacji powinna być produktem konsensusu, a przedsiębiorstwa nie mogą dla uzyskania zgody uciekać się do manipulacji (UN Doc. A/HRC/21/47 2012: §67).

Różnice kulturowe i językowe mogą stanowić istotne przeszkody w procesie zawierania porozumień. Przedsiębiorstwa coraz częściej zapewniają swoim pracownikom szkolenia z zakresu świadomości kulturowej dla swoich pracowników, tak aby wspomóc proces komunikacji (MiningFacts.org 2012: 1). Praktykuje się także zobowiązywanie pracowników do nauki języka lokalnego w celu wspólnego wypracowywania definicji terminów technicznych, dla których języki lokalne mogą nie mieć odpowiedników. Pracownicy są ponadto motywowani do rozwijania kompetencji miękkich, służących zrozumieniu tradycji prawnych i kulturowych każdej ze stron (Centre for Social Responsibility in Mining 2012: 54).

Ludność rdzenna ma prawo do pomocy technicznej i finansowej ze strony przedsiębiorstwa przystępującego do projektu na potrzeby zapewnienia środków do finansowania operacjonalizacji postępowania w przedmiocie udzielenia zgody (UN Declaration on the Rights of Indigenous Peoples art. 4, 39, 75). Pomoc ta ma na celu ustanowienie równowagi sił między ludnością rdzenną i podmiotami występującymi o udzielenie zgody, a także budowanie zdolności negocjacyjnych ludności rdzennej, tak aby umożliwić skutecznie angażowanie się w aktywność konsultacyjną (UN Doc. A/HRC/21/47 2012: §37). Przekazanie przez przedsiębiorstwo pieniędzy i innych środków finansowych niezbędnych dla zapewnienia skutecznego udziału społeczności w procesie negocjacyjnym służy wzmocnieniu zdolności danej społeczności do 
świadomego kształtowania swojego rozwoju poprzez poprawę jej kapitału ekonomicznego i ludzkiego (InterGroup Consultants 2008: 25).

Zakotwiczenie prawa do udzielenia lub cofnięcia zgody w prawie do samostanowienia oznacza, że w przypadku, gdy dana społeczność nie chce przystąpić do konsultacji z osobą trzecią lub państwem, nie należy nakładać na nią takiego obowiązku, a w konsekwencji - udzielenie lub cofnięcie zgody jest prawem danej społeczności, a nie jej obowiązkiem (Report of the international expert group meeting on extractive industries 2009: §13).

\section{Uczestnictwo narodów UE w realizacji zasad prawa środowiska UE}

UE składa się obecnie z 28 państw, z których każde ma ustalony co najmniej jeden język urzędowy. Na terytorium państw członkowskich UE występują łącznie trzy alfabety: łaciński, grecki, i cyrylica (wersja bułgarska). Językami roboczymi instytucji UE są natomiast języki: angielski, francuski i niemiecki. UE nie ma jednego języka, który byłby symbolem jej tożsamości i emocjonalnie łączył jej obywateli, przeciwnie - zgodnie z oficjalnym stanowiskiem UE, językowym symbolem jej tożsamości jest wielojęzyczność. To właśnie zróżnicowanie decyduje bowiem o tożsamości Unii Europejskiej: ma ona być „wspólnym domem, w którym ceni się różnorodność”, gdzie ,języki macierzyste stanowią źródło bogactwa i pomost dla większej solidarności i wzajemnego zrozumienia" (COM/2005/596). Art. 10 ust. 3 Traktatu o Unii Europejskiej (dalej TUE, Dz. Urz. UE C 326 , 26.10.2012: 13-46) stanowi, że każdy obywatel ma prawo uczestniczenia w życiu demokratycznym UE. Ściśle związany jest z nim art. 11 ust. 1 TUE, który zobowiązuje instytucje do zapewnienia obywatelom i stowarzyszeniom przedstawicielskim wypowiadania się i publicznej wymiany poglądów we wszystkich dziedzinach działania UE. Z uwagi na wielojęzyczność UE, dla zwiększenia uczestnictwa obywateli w życiu demokratycznym, a tym samym przyczynienia się do legitymizacji UE, musi ona zapewnić możliwość używania języków jako instrumentów służących do osiągnięcia celów wskazanych tymi przepisami. Regulacje te są oparte na koncepcji podwójnej legitymacji, częściowo pochodzącej z parlamentów krajowych, częściowo z udziału obywateli UE w wyborach do Parlamentu Europejskiego (M. Rufert 2011: pkt 5 i 12). Takie uczestnictwo jest możliwe, jeśli obywatele mogą używać swojego języka ojczystego lub przynajmniej oficjalnego języka państwa zamieszkania. Dlatego właśnie wszystkie wersje językowe tekstów ustawodawczych są jednakowo autentyczne. Koncepcję tę dodatkowo wzmacnia art. 24 ust. 4 Traktatu o funkcjonowaniu Unii Europejskiej (dalej TFUE, Dz. Urz. UE C 326, 26.10.2012: 47-390) stanowiący, że każdy obywatel UE może zwracać się pisemnie do każdej instytucji lub organów, w jednym z języków wskazanych w art. 55 ust. 1 TUE i otrzymać odpowiedź w tym samym języku.

Ochrona środowiska stanowi jeden z celów traktatowych, który musi zostać osiągnięty w możliwie najwyższym stopniu, w praktycznym powiązaniu z innymi celami, W szczególności ekonomicznymi i socjalnymi, tak aby faktycznie zapewnić wysoki poziom ochrony (J. Osiejewicz 2016: 90-91, 195-197). Zasady europejskiego prawa środowiska mają swoje źródło w międzynarodowym prawie środowiska. Wyróżnia 
się wśród nich między innymi: zasadę zrównoważonego rozwoju, zasadę przezorności i prewencji, zasadę „zanieczyszczający płaci” oraz zasadę naprawienia szkody u źródła. Terminologia europejskiego prawa środowiska została pierwotnie ukształtowana przez instytucje i porozumienia Organizacji Narodów Zjednoczonych (dalej ONZ). UE ratyfikowała wszystkie najważniejsze umowy międzynarodowe dotyczące środowiska, a ich terminologia stała się częścią żargonu UE.

Koncepcja zrównoważonego rozwoju jest powszechnie wykorzystywana w wielu obszarach prawa UE, jednak jej treść nie została objaśniona. Termin ten pojawił się po raz pierwszy w raporcie zatytułowanym „Nasza wspólna przyszłość”, przedłożonym w 1987 r. Zgromadzeniu Ogólnemu ONZ przez Światową Komisję ds. Środowiska i Rozwoju. W tym raporcie zrównoważony rozwój został opisany jako rozwój odpowiadający potrzebom teraźniejszości, nie zmniejszający zdolności przyszłych pokoleń do zaspokojenia ich własnych potrzeb (J. Ciechanowicz-MacLean 2015: 2010). Pojęcie zrównoważonego rozwoju zostało wprowadzone do prawodawstwa UE przez Traktat Amsterdamski w 1999 r., jednak bez jego zdefiniowania (Dz.U. C 340 z 10.11.1997: 1-144, art. 3 ust. 3 TFUE i art. 11 TFUE). Treść pojęciowa tego terminu pozostaje nadal niejasna (L. Krämer 2012: 9). Wydaje się jednak oczywiste, że polityka wzrostu gospodarczego, która nie uwzględniałaby uwarunkowań środowiskowych, nie spełniałaby kryterium zrównoważonego rozwoju. Ciągłe kształtowanie i rozszerzanie zakresu stosowania tego terminu prowadzi jednak do konkluzji, że jest on coraz częściej używany jako substytut ,pozytywnego, korzystnego rozwoju” i zaczyna tracić swoją pierwotną treść środowiskową (L. Krämer 2012: 11).

Zasada prewencji i przezorności (występująca również w jęz. polskim pod nazwą zasady ostrożności i działania zapobiegawczego) jest jedną z podstawowych zasad europejskiego prawa ochrony środowiska. Nie jest jednak jasne, $w$ jakim zakresie zasada prewencji jest niezależna od zasady przezorności, ponieważ w praktyce obie zasady są prawie zawsze używane łącznie i żadna z nich nie posiada definicji traktatowej (L. Krämer 2012: 25). Kruchość jedności obu koncepcji można wykazać na przykładzie angielskiej i innych wersji językowych wyroku w sprawach C-157/96 (§63-64) i C-180/96 (\$99-100). Wersja angielska wyroku dotyczy wyłącznie prewencji i nie rozróżnia obydwu pojęć (prevention principle), natomiast wersja niemiecka (Grundsätze der Vorsorge und Vorbeugung), hiszpańska (principios de cautela y de acción preventiva), duńska (forsigtighedsprincippet i princippet om forebyggende indsats) $\mathrm{i}$ francuska (principes de précaution et d'action preventive) stosują wyrażenie uwzględniające obydwa elementy. Zasada prewencji wydaje się wymagać wstępnych działań przeciwko znanym i oczekiwanym oddziaływaniom, a połączona z zasadą ostrożności ostrzega, że przy zachowaniu należytej staranności można i należy unikać nieoczekiwanych konsekwencji. Trybunał Sprawiedliwości Unii Europejskiej dokonał wykładni tej zasady w odniesieniu do zapobiegania powstawaniu odpadów (C-418/97 i C-419/97: §39, C-6/03: §28-30, C-194/05: §33 i §20).

Zasada ,zanieczyszczający płaci” została po raz pierwszy zdefiniowana przez OECD w 1972 r. (OECD ACTS 1992: 13-16). Zasadę tę wprowadziła do prawa UE dyrektywa 2004/35/WE w sprawie odpowiedzialności za środowisko. Problemy z efektywnością jej wdrożenia (U. Salanitro 2015) wynikały między innymi z braku 
jasnej definicji i jednolitego podejścia do tej zasady (patrz także M. Kenig-Witkowska 2011: 98-99). Z językowego punktu widzenia szczególne wyzwanie polega na tym, że jęz. angielski, będący językiem źródłowym, wykorzystuje w określniku strukturę łączącą rzeczownik z czasownikiem (polluter pays principle). Taka konstrukcja jest trudna do wyrażenia szczególnie w przypadku języków aglutynacyjnych (np. węgierski) i fleksyjnych (np. polski). Zastosowano w tym przypadku różne rozwiązania, od tłumaczenia dosłownego (np. szwedzki, litewski, bułgarski), poprzez formę złożoną z dwóch rzeczowników, którą można wyrazić w języku angielskim jako „polluterpayer" (np. francuski, portugalski), aż do wersji niemieckiej, która odbiegając od oryginalnej formy gramatycznej stosuje wyrażenie opowiadające ,zasadzie związku przyczynowego" (Verursacherprinzip) (European Commission 2010: 114).

Zasada naprawienia szkody w pierwszym rzędzie u źródła (principle of the rectification of damage at source) została włączona do prawa traktatowego Traktatem Amsterdamskim w 1987 r. Część wersji językowych odpowiada angielskiemu wyrażeniu damage (m. in. włoska, polska, szwedzka, słowacka, rumuńska, czeska i niemiecka), natomiast część angielskiemu wyrażeniu impairment wskazującemu raczej na skutki zdarzenia niż na samo zdarzenie szkodowe ( $\mathrm{m}$. in. francuska i belgijska). Nie jest ponadto jasno określone, co konkretnie oznacza wyraz „naprawienie” (L. Krämer 2012: 26). Pojęcia te podlegały dopiero partykularnej wykładni Trybunału Sprawiedliwości UE (C-2/90: §34; C-293/97: §44, 52).

\section{Wnioski}

Ludy tubylcze i narody UE to niewątpliwie bardzo odmienne grupy, funkcjonujące w różnych warunkach społecznych, ekonomicznych i cywilizacyjnych. Z perspektywy prawnomiędzynarodowej wszystkie te grupy są jednak narodami, cechującymi się wspólną tożsamością obejmującą kulturę duchową, kulturę materialną, historię i język (M. Muszyński 2010: 77), osiadłymi na terytorium przynależnym do państwa (G. Jellinek 1966: 406). W świetle prawa międzynarodowego każdemu z tych narodów przysługują prawa dotyczące środowiska, wynikające z prawa do samostanowienia i z zasady suwerenności narodów nad zasobami naturalnymi. Realizacja tych praw jest możliwa między innymi wtedy, gdy dzięki zachowaniu sprawiedliwości językowej narody te mogą efektywnie uczestniczyć w kierowaniu sprawami publicznymi. Sprawiedliwość językowa sprowadza się w tym przypadku do przekazania informacji tym narodom w taki sposób, aby były one w stanie zrekonstruować wiedzę stanowiącą podstawę komunikatu i świadomie na ten komunikat odpowiedzieć. Na sprawiedliwość językową składają się zatem dwa elementy: właściwy kanał komunikacji oraz odpowiedni sposób wyrażenia wiedzy specjalistycznej w aspekcie materialnym i formalnym.

Po pierwsze, konieczne jest zastosowania takiego kanału komunikacji, który jak najlepiej umożliwi skuteczne zaadresowanie komunikatu. W przypadku ludów tubylczych oznacza to najpierw zidentyfikowanie właściwej grupy adresatów komunikatu, następnie zidentyfikowanie właściwych przedstawicieli tej grupy, a na koniec nawiązanie z nimi bezpośredniego kontaktu. Ludność rdzenna ma przy tym prawo wzmacniać lub modyfikować swoje instytucje, a nawet tworzyć nowe struktury reprezentacji 
dla ułatwienia ich zaangażowania $\mathrm{w}$ procesy decyzyjne. W przypadku narodów UE kanałem komunikacji jest stanowienie prawa przez instytucje UE i stosowanie prawa UE. Narody UE mają wpływ na wybór swoich przedstawicieli do Parlamentu Europejskiego, nie mają jednak wpływu na późniejsze procesy stanowienia i stosowania prawa.

Po drugie, konieczne jest zastosowanie takiego sposobu wyrażania wiedzy, który będzie odpowiedni do osiągnięcia celu, jakim jest prawidłowe (jak najbardziej zbliżone do treści komunikatu wyjściowego oraz odzwierciedlające intencje autora komunikatu) zrekonstruowanie komunikatu przez odbiorców. Można tutaj wyodrębnić dwa aspekty: materialny i formalny. Aspekt materialny odnosi się do treści merytorycznej przekazu. W przypadku ludów tubylczych komunikacja jest nakierowana na wzmocnienie pozycji tej ludności i budowania równowagi sił między tą ludnością a podmiotami występującymi o wyrażenie przez nią zgody. Oznacza to, że przedsiębiorstwa i/ lub rządy czynią starania i są aktywnie zaangażowane w doprowadzenie do jak najpełniejszego zrozumienia przez tę ludność kierowanego do niej komunikatu. Wśród narodów UE silnie zakorzeniona jest natomiast rzymska kultura prawna z jej naczelną paremią ignorantia iuris nocet, uznającą fikcję powszechnej znajomości prawa. Hołdowanie jej treści jest równoznaczne z przerzuceniem ciężaru odpowiedzialności za efekt komunikacyjny na odbiorcę, to jest na naród UE. Wprawdzie instytucje unijne czynią starania o rozpowszechnianie wiedzy na temat działań podejmowanych przez UE, $w$ tym $w$ obszarze środowiska, jednak przeciętny przedstawiciel narodu UE rzadko ma do niej dostęp, jeśli nie podejmie aktywności w tym kierunku. W odniesieniu do aspektu formalnego, dotyczącego formy przekazu i procedur komunikowania, należy zwrócić uwagę na adekwatność terminologiczną przekazu i sposób dostarczenia komunikatu. Przedsiębiorstwa coraz częściej zapewniają szkolenia z zakresu świadomości kulturowej i zwyczajów lokalnych dla swoich pracowników, tak aby wspomóc proces komunikacji z ludnością rdzenną. Zobowiązują też swoich pracowników do nauki języka lokalnego, wspierają wspólne wypracowywanie definicji terminów technicznych, dla których języki lokalne mogą nie mieć odpowiedników, a także oczekują od pracowników rozwijania kompetencji miękkich, służących zrozumieniu tradycji prawnych i kulturowych danej grupy. Odnośnie do procedur komunikacji z narodami UE, warto podkreślić dbałość o poszanowanie wszystkich języków urzędowych państw członkowskich wyrażające się m.in. w uznaniu ich za języki autentyczne prawa traktatowego UE. Zasady prawa ochrony środowiska UE nie są jednak zdefiniowane $\mathrm{w}$ prawie pierwotnym UE. Ich merytoryczne znaczenie zostało poddane dyskusji akademickiej, w większości kończącej się konkluzją, że nie jest możliwe wypracowanie ich jasnych definicji (patrz np. A. Epiney 2006: 19-39, T. Tridimas 2006: 25-35, L. Krämer 2012: 25-27, N. de Sadeleer 2014: 40-92, E. Scotford 2017: 3.II.B). Do objaśniania znaczenia tych zasad przyczyniły się jedynie partykularnie dyrektywy i ich wykładnia przez Trybunał Sprawiedliwości UE. Nie sprzyja to komunikacji w warunkach wielojęzyczności.

W doktrynie prawa międzynarodowego zwraca się obecnie uwagę na drugorzędne traktowanie sprawiedliwości w sferze instytucjonalnej prawa międzynarodo- 
wego, a nawet mówi się o jej deficycie w kontekście tak rozwiniętej organizacji ponadnarodowej, jaką jest UE (A. Wiśniewski 2016: 503, patrz obszernie D. Kochenov/ G. de Burca/ A. Williams 2015). Zastosowanie różnych kanałów komunikacji do ludności tubylczej i narodów UE wydaje się zasadne, z uwagi na to, że jako narody wykazują one znaczne odrębności. Podobnie na pierwszy rzut oka nie dziwią różnice proceduralne oraz odmienne postrzeganie osiągnięcia skuteczności komunikatu $\mathrm{w}$ aspekcie formalnym. Na pytanie, czy te sposoby komunikacji sprzyjają zachowaniu sprawiedliwości językowej, odpowiedniej dla każdej z tych grup, trudno jednak udzielić jednoznacznej odpowiedzi. Dla osiągnięcia sprawiedliwości językowej konieczne jest niewątpliwie zmierzenie się z problemami, które są właściwe odrębnie dla każdej z grup narodów. W przypadku ludów tubylczych będą to: ich woluntatywna izolacja, nierówność płci i lokalne konflikty zbrojne. W przypadku narodów UE są to: znaczące problemy terminologiczne występujące $\mathrm{w}$ warunkach wielojęzyczności oraz trudności związane z nieprzejrzystością informacji kierowanej do obywateli UE.

\section{Bibliografia}

Buchanan, A./ D. Golove (2012), Philosphy of International Law, (w:) J. Coleman/ S. Shapiro (red.), The Oxford Handbook of Jurisprudence and Philosophy of Law. Oksford, 868-934.

Ciechanowicz-McLean, J. (2015), Prawo ochrony i zarządzania środowiskiem. Warszawa.

Corntassel, J. (2008), Who is Indigenous? (w:) C. Erni (red.), The Concept of Indigenous Peoples in Asia. A Resource Book. Kopenhaga, 51-74.

Daes, E.-I. (2008), Indigenous peoples. Keepers of our past-custodians of our Future. Kopenhaga.

de Sadeleer, N. (2014), EU Environmental Law and the Internal Market. Oxford.

Doyle, C. (2012), Indigenous Peoples, Title to Territory, Rights \& Resources: The Transformative Role of Free Prior \& Informed Consent. Middlesex.

Epiney, A. (2006), Environmental Principles, (w:) R. Macrory (red.), Reflections on 30 Years of EU Environmental Law. Groningen 2006.

Gawłowicz, I. (2005), Nowe rozumienie suwerenności jako signum temporis, (w:) I. Gawłowicz/ I. Wierzchowiecka (red.), Koncepcje suwerenności. Zbiór studiów. Warszawa, 26-42.

Grucza, F. (2002), Języki specjalistyczne - indykatory i/lub determinatory rozwoju cywilizacyjnego, (w:) J. Lewandowski (red.), Języki specjalistyczne 2. Problemy technolingwistyki. Warszawa, 9-26.

Grucza, S. (2010), Język a poznanie - kilka uwag na temat rozważania ich wzajemnych relacji, (w:) S. Grucza/ A. Marchwiński/ M. Płużyczka (red.), Translatoryka. Koncepcje - Modele - Analizy. Warszawa, 54-67.

Jellinek, G. (1966), Allgemeine Staatslehre. Bad Hamburg etc.

Kenig Witkowska, M. (2011), Prawo środowiska Unii Europejskiej: Zagadnienia systemowe. Warszawa.

Kochenov, D./ G. de Burca/ A. Williams (2015), Europe's Justice Deficit. Oxford. 
Krämer, L. (2012), EU Environmental Law. Londyn.

Loutit, J./ J. Mandelbaum/ S. Szoke-Burke (2016), Emerging Practices in community development agreements, (w:) „Columbia University Academic Commons” 7, 64-96.

Muszyński, M. (2010), Państwo w prawie międzynarodowym. Istota, rodzaje $i$ atrybuty. Bielsko Biała.

Osiejewicz, J. (2016), Harmonizacja prawa państw członkowskich Unii Europejskiej. Warszawa.

Osiejewicz, J. (2017a), Human Rights Due Diligence of Business Enterprises under the UN Guiding Principles on Business and Human Rights, (w:) M. Dei (red.), Human Rights: Theory and Practice. Londyn, 152-155.

Osiejewicz, J. (2017b), Prawo ludności tubylczej do czystego środowiska naturalnego w konfrontacji z wydobyciem ropy naftowej $w$ Delcie Nigru, (w:) J. Jaskiernia/ K. Spryszak (red.), Ochrona praw człowiek w Afryce. Aksjologia - instytucje - nowe wyzwania - praktyka. Toruń, 445-459.

Ross, M.L. (2012) The Oil Curse: How Petroleum Wealth Shapes the Development of Nations. Princeton.

Rufert, M. (2011), Art. 10 EUV, (w:) Ch. Callies/ M. Ruffert (red.), EUV/AEUV. Das Verfassungsrecht der Europäischen Union mit Europäischer Grundrechtcharta. Kommentar. Monachium.

Salanitro, U. (2015), Directive 2004/35/EC on Environmental Liability. Study in the framework of the EFFACE research project University of Catania. Catania

Scotford, E. (2017), Environmental Principles and the Evolution of Environmental Law. Bloomsbury.

Soniewicka, M. (2010), Sprawiedliwość globalna - przegląd wybranych zagadnień. (URL http://www.incet.uj.edu.pl/dzialy.php?l=pl\&p=32\&i=1\&m=22\&z=0\&n $=2 \& \mathrm{k}=13$ ). [Pobrano 24.07.2017].

Tridimas, T. (2006), The General Principles of EU Law. Oxford.

Wieruszewski, R. (2012), Artykut 27. Ochrona mniejszości, (w:) R. Wieruszewski (red.), Międzynarodowy Pakt Praw Obywatelskich (Osobistych) i Politycznych. Komentarz. Warszawa, 682-695.

Wiesner, S. (1999), Rights and Status of Indigenous Peoples: A Global Comparative and International Legal Analysis, (w:) „Harvard Human Rights Journal” 12, 57128.

Wiśniewski, A. (2016), Prawo międzynarodowe a sprawiedliwość, (w:) „Gdańskie Studia Prawnicze" XXV, 501-518.

Zajadło, J. (2007), Sprawiedliwość, (w:) J. Zajadło (red.), Leksykon współczesnej teorii i filozofii prawa. 100 podstawowych pojęć. Warszawa.

\section{Akty prawne}

Międzynarodowy Pakt Praw Obywatelskich i Politycznych otwarty do podpisu w Nowym Jorku dnia 19 grudnia 1966 r., Dz. U. 1977 nr 38 poz. 167.

Międzynarodowy Pakt Praw Gospodarczych, Społecznych i Kulturalnych otwarty do podpisu w Nowym Jorku dnia 19 grudnia 1966 r., Dz. U. 1977 nr 38 poz. 169. 
International Labour Organisation, Indigenous and Tribal Peoples Convention, Geneva, 27.06.1989, C 169.

Konwencja o dostępie do informacji, udziale społeczeństwa w podejmowaniu decyzji oraz dostępie do sprawiedliwości w sprawach dotyczących Środowiska, sporządzona w Aarhus dnia 25 czerwca 1998, Dz. U. nr 78 poz. 706.

Economic and Social Council resolution 1346 (XLV) of 30 July 1968, Question on convening an international conference on the problems of human environment. (URL http://www.securitycouncilreport.org/atf/cf/\%7B65BFCF9B-6D27-4E9C8CD3-CF6E4FF96FF9\%7D/UNMembers\%20ARES2384\%20XXIII.pdf). [Pobrano 24.07.2017].

General Recommendation 23, Rights of indigenous peoples (Fifty-first session, 1997), U.N. Doc. A/52/18, annex V at 122 (1997), reprinted in Compilation of General Comments and General Recommendations Adopted by Human Rights Treaty Bodies, U.N. Doc. HRI/GEN/1/Rev.6 at 212 (2003).

United Nations Economic and Social Council, Rio Declaration on Environment and Development, Report of the Secretary-General, Commission on Sustainable Development, Fifth session, 7-25 April 1997, E/CN.17/1997/8.

Committee on the Elimination of Racial Discrimination, General Recommendation 25, Gender Related Dimensions of Racial Discrimination (Fifty-sixth session, 2000), U.N. Doc. A/55/18, annex V at 152 (2000), reprinted in Compilation of General Comments and General Recommendations Adopted by Human Rights Treaty Bodies, U.N. Doc. HRI/GEN/1/Rev.6 at 214 (2003).

Resolution adopted by the General Assembly, 13.09.2007, United Nations Declaration on the Rights of Indigenous Peoples (UNDRIP), A/RES/61/295.

Report of the international expert group meeting on extractive industries, Indigenous Peoples' rights and corporate social responsibility E/C.19/2009/CRP, 4 May 2009.

Report by the Special Rapporteur on the situation of human rights and fundamental freedoms of indigenous people, James Anaya - Addendum - Report on the situation of indigenous peoples in Nepal, A/HRC/12/34, 20 July 2009.

CERD Concluding Observation to the Philippines UN Doc. CERD/C/PHL/CO/20 (23 September 2009).

General Comment 21, Right of everyone to take part in cultural life, E/C.12/GC/21, 21 December 2009, GE.09-46922.

Nagoya Protocol on Access to Genetic Resources and the Fair and Equitable Sharing of Bene ts Arising from their Utilization to The Convention On Biological Diversity. Nagoya, 29 October 2010 C.N.782.2010.TREATIES-1 (Depositary otication).

Report to the General Assembly of the Special Rapporteur on the rights of indigenous peoples, James Anaya, UN Doc. A/66/288 (10 August 2011), Summary of activities. The impacts of extractive industries on indigenous peoples.

Report to the General Assembly of the Special Rapporteur on the rights of indigenous peoples, James Anaya, UN Doc. A/HRC/21/47 (6 July 2012), Promotion and protection of all human rights, civil, political, economic, social and cultural rights, including the right to development. 


\section{Prawo Unii Europejskiej}

Traktat o Unii Europejskiej, Dz. Urz. UE C 326, 26.10.2012: 13-46.

Traktat o funkcjonowaniu Unii Europejskiej, Dz. Urz. UE C 326, 26.10.2012: 47390.

Traktat z Amsterdamu, Dz.U. C 340 z 10.11.1997: 1-144.

Traktat ustanawiający Wspólnotę Europejską, Dz.U. C 340 z 10.11.1997: 173-306.

Dyrektywa 2004/35/WE Parlamentu Europejskiego i Rady z dnia 21 kwietnia 2004 r. $\mathrm{w}$ sprawie odpowiedzialności za środowisko w odniesieniu do zapobiegania i zaradzania szkodom wyrządzonym środowisku naturalnemu, Dz.U. L 143 z 30.4.2004: 56-75.

Decyzja Rady 2005/370/WE z dnia 17 lutego 2005 r. w sprawie zawarcia w imieniu Wspólnoty Europejskiej Konwencji o dostępie do informacji, udziale społeczeństwa w podejmowaniu decyzji oraz dostępie do sprawiedliwości w sprawach dotyczących środowiska, Dz. Urz. UE L 186, 19.7.2017: 15-16.

Komunikat Komisji do Rady, Parlamentu Europejskiego, Komitetu EkonomicznoSpołecznego oraz Komitetu Regionów z 22.11.2005 Nowa strategia ramowa w sprawie wielojęzyczności, COM(2005) 596.

\section{Konwencje regionalne}

Organization of American States, American Convention on Human Rights „Pact of San Jose”, Costa Rica, 22.11.1969, OAS Treaty Series No. 36; 9 ILM 99 (1969).

Organization of African Unity (OAU), African Charter on Human and Peoples' Rights („Banjul Charter”), 27.06.1981, CAB/LEG/67/3 rev. 5, 21 I.L.M. 58 (1982).

\section{Dokumenty}

Joint Working Group on Indigenous Land Settlements, Guidelines for best practice, flexible and sustainable agreement making, August 2009.

The World Bank's Operational Policy 4.10, July 2005, Annex A.

Representation (art. 24) - Guatemala - C169-2007 - Report of the Committee set up to examine the representation alleging non-observance by Guatemala of the Indigenous and Tribal Peoples Convention, 1989 (No. 169), made under article 24 of the ILO Constitution by the Federation of Country and City Workers (FTCC) Submitted: 2005 Document: (GB.294/17/1).

Centre for Social Responsibility in Mining, Agreement-making with Indigenous Groups: Oil \& Gas Development, Australia 2012, 58.

MiningFacts.org, Case Study: Diavik Diamond Mine, (w:) What Are Impact and Benefit Agreements?2012.(URL http://www.miningfacts.org/Communities/What-are-Impactand-Benefit-Agreements -(IBAs)/). [Pobrano 23.02.2017].

Report of the international expert group meeting on extractive industries, Indigenous Peoples' rights and corporate social responsibility E/C.19/2009/CRP. 8, 4 May 2009. 
OECD ACTS, Guiding principles concerning international economic aspects of environmental policies, Recommendation adopted on 26th May, 1972) C(72)128, (w:) The Polluter-Pays Principle, OECD Analyses and Recommendations, OCDE/GD(92)81, 13-16.

European Commission, Directorate General For Translation, Study on Lawmaking in the EU Multilingual Environment, 1/2010.

\section{Orzecznictwo}

Trybunał Sprawiedliwości UE, 09.07.1992, Komisja Wspólnot Europejskich v. Królestwo Belgii, C-2/90, Zbiór Orzeczeń 1992 I-04431.

Trybunał Sprawiedliwości UE, 05.05.1998, The Queen v. Ministry of Agriculture, Fisheries and Food, Commissioners of Customs \& Excise, C-157/96, Zb. Orz. 1998 I-02211.

Trybunał Sprawiedliwości UE, 05.05.1998, Zjednoczone Królestwo Wielkiej Brytanii i Irlandii Północnej v. Komisja Wspólnot Europejskich, C-180/96, Zb. Orz. 1998 I-02265.

Trybunał Sprawiedliwości UE, 29.04.1999, The Queen przeciwko Secretary of State for the Environment i Ministry of Agriculture, Fisheries and Food, C-293/97, Zb. Orz. 1999 I-02603, C-293/97.

Trybunał Sprawiedliwości UE, 15.06.2000, ARCO Chemie Nederland Ltd v. Minister van Volkshuisvesting, Ruimtelijke Ordening en Milieubeheer (C-418/97) i Vereniging Dorpsbelang Hees, Stichting Werkgroep Weurt+ i Vereniging Stedelijk Leefmilieu Nijmegen v. Directeur van de dienst Milieu en Water van de provincie Gelderland (C-419/97), Zb. Orz. 2000 I-04475.

Trybunał Sprawiedliwości UE, 14.04.2005, Deponiezweckverband Eiterköpfe v. Land Rheinland-Pfalz, C-6/03, Zb. Orz. 2005 I-02753.

Trybunał Sprawiedliwości UE, 18.12.2007, Komisja Wspólnot Europejskich v. Rebublika Włoska, C-194/05, Zb. Orz. 2007 I-11661.

Inter-American Court on Human Rights, 12.08.2008, Saramaka People v. Suriname, Interpretation of the Judgment of Preliminary Objections. Series C No. 185. 